\title{
Alkaloids from the seed, calyx, and corolla of Erythrina americana Miller and Erythrina coralloides A.DC.
}

\author{
Sánchez-Herrera, Susana G. ${ }^{1}{ }^{\oplus}$; Soto-Hernández, Ramón $\operatorname{Marcos}^{1}{ }^{\oplus}$; Garín-Aguilar, María E. ${ }^{2}{ }^{\oplus}$; \\ Vibrans-Lidermann, Heike ${ }^{1}{ }^{\mathbb{D}}$; García-Mateos, María del Rosario $^{3}{ }^{\mathbb{D}}$; \\ Martínez-Vázquez, Mariano ${ }^{4}$ (i) \\ ${ }^{1}$ Colegio de Postgraduados, Postgrado en Botánica, Carretera México-Texcoco Km. 36.5, Texcoco, Estado \\ de México, México, C.P.56230. \\ 2 Facultad de Estudios Superiores Iztacala, Universidad Nacional Autónoma de México, Av. de los Barrios \\ s/n., Los Reyes Iztacala, Tlalnepantla, Estado de México, México, C.P. 54090. \\ 3 Departamento de Fitotecnia, Universidad Autónoma Chapingo, Texcoco, Edo. de México, México, G.P. \\ 56230. \\ 4 Facultad de Química, Universidad Nacional Autónoma de México, Circuito Exterior S/N, Coyoacán, \\ Giudad Universitaria, Ciudad de México. México, G.P. 04510. \\ * Correspondence: suzzana@colpos.mx
}

Gitation: Sánchez-Herrera, S. G.,

Soto-Hernández, R. M., Garín-Aguilar, M. E., Vibrans-Lidermann, H.,

García-Mateos, M. del R., \& MartínezVázquez, M. (2021). Alkaloids from the seed, calyx, and corolla of Erythrina americana Miller and Erythrina coralloides A.DC. Agro Productividad. https://doi. org/10.32854/agrop.v14i12.2025

Editor in Chief: Dr. Jorge Cadena Iñiguez

Received: May 4, 2021.

Accepted: December 12, 2021.

Published on-line: December 30, 2021.

Agro Productividad, 14(12). December. 2021. pp: 153-157.

This work is licensed under a Creative Commons Attribution-NonCommercial 4.0 International license.

\section{ABSTRACT}

Objective: To identify the main alkaloids present in the seeds, calyx, and corolla of E. americana and E. coralloides (Fabaceae) using HPLC-MS.

Design/methodology/approach: The seeds, calyx, and corolla of both species were separated; the crude alkaloid extracts were prepared according to the method described by Games et al. (1974). The crude alkaloid extracts were analyzed using a high-performance liquid chromatograph interfaced to a quadrupole ion trap mass spectrometer.

Results: The lactonic alkaloids $-\alpha$-erythroidine and $\beta$-erythroidine were the main alkaloids found in $E$. americana, whereas the presence of erythrinine and 8-oxo erythraline is typical of E. coralloides. These compounds can be used to distinguish both species.

Limitations on study/implications: The use of the HPLC-MS technique allowed the detection of a large numbers of alkaloidal structures in different parts of the plants; however, this technique is not available in any laboratory.

Findings/conclusions: A large number of erythrinane-like alkaloids were found in seed, calyx, and corolla. The use of seeds and flowers in the preparation of diverse traditional dishes can cause soothing and sedating effects in consumers, as a result of the presence of lactonic alkaloids. The HPLC-MS method allowed the detection of alkaloidal structures in flowers and seeds that had not been identified in previous studies about this species.

Keywords: Alkaloids; chemotaxonomy; liquid chromatography-mass spectrometry. 


\section{INTRODUCTION}

The search for new active ingredients of natural origin based on the traditional use of certain plants is a well-documented fact. The genus Erythrina (Fabaceae) is one of the many Mexican plants used in traditional medicine. Several species of this genus are distributed throughout the world and a large number of these have been found in Mexico. In recent years the genus Erythrina was the subject of various researches throughout the world. Different aspects of the presence of flavonoids (Kumar et al., 2013; Tanaka et al., 2002; Chukwujekwu et al., 2011), lectins (Turton et al., 2004), or alkaloids (Garín-Aguilar et al., 2005) have been studied. In particular, the following aspects of alkaloids have been the subject of study: structural analysis, biosynthesis (Maier et al., 1999), pharmacology (Dantas et al., 2004, Setti-Perdigão et al., 2013, Saidu et al., 2000), or chemotaxonomy (Yoshida et al., 2009).

Previous studies have reported the presence of various alkaloids, but especially those that have an effect on the peripheral nervous system. These alkaloids include erysodine, an alkaloid isolated from the seeds of the genus Erythrina, which is an antagonist of neuronal nicotinic receptors $\alpha 4 \beta 2$. This alkaloid was used to determine the role that these receptors play in memory consolidation (Garín-Aguilar et al., 2009).

Two species of Erythrin, E. americana and E. coralloides, were studied to determine the alkaloid profile of their respective seeds and flowers (calyx and corolla), and therefore to compare their chemotaxonomic identity (Krukoff and Barneby, 1973).

\section{MATERIALS AND METHODS}

Seeds and flowers of E. coralloides and E. americana were collected in Texcoco and in Colorines, respectively; both towns are located in the State of Mexico. Specimens of each of the species were deposited in the CHAPA herbarium (Postgrado en Botánica, Colegio de Posgraduados). The authenticity of the specimens was certified by Mr. Joaquin Becerra Zabala from the CHAPA herbarium.

The flowers of both species were separated into calyx and corolla, and dehydrated in a Felisa FE-291 drying oven.

Crude extracts were prepared according to the method described by Games et al. (1974) for the extraction of alkaloids. Each plant material was extracted with hexane in a Soxhlet equipment for 48 hours. Vacuum evaporation was applied to the solvent and the residue was washed with $2 \% \mathrm{H}_{2} \mathrm{SO}_{4}$; afterwards, the $\mathrm{pH}$ of the acidic phase was adjusted to 8 using $\mathrm{NaHCO}_{3}$. Finally, extractions were carried out with $\mathrm{CH}_{2} \mathrm{Cl}_{2}(3 \times 100)$, obtaining the hexane fraction of "free" alkaloids. The plant material was once more extracted with $\mathrm{CH}_{3} \mathrm{OH}$ in the Soxhlet, the solvent was vacuum evaporated, and the residue was washed with $2 \% \mathrm{H}_{2} \mathrm{SO}_{4}$. The acidic solution was extracted with $\mathrm{CH}_{2} \mathrm{Cl}_{2}(3 \times 100)$ to remove traces of fat, and later adjusted to a $\mathrm{pH}$ of 8 with $\mathrm{NaHCO}_{3}$, obtaining the methanolic fraction of "free" alkaloids.

The aqueous phase was acidified to a pH of 2 with $\mathrm{HCl}$ and refluxed at $60{ }^{\circ} \mathrm{C}$ for 3 hours to hydrolyze the esterified alkaloids. Then, the solution was adjusted to a $\mathrm{pH}$ of 8 and extracted with $\mathrm{CH}_{2} \mathrm{Cl}_{2}(3 \times 100)$ to obtain the fraction of "released" alkaloids. 
The alkaloid extracts were analyzed using the liquid chromatography-mass spectrometry (HPLG-MS) technique. For this purpose, the crude extract was analyzed using a Waters 600 high-performance liquid chromatograph, connected with a Finnigan LCQ mass spectrometer, using an atmospheric pressure chemical ionization (APCI) source. The alkaloids were separated by means of a $250 \mathrm{~mm} \times 4.6 \mathrm{~mm}$ Superco Discovery C-18 (5um) column, at a $1 \mathrm{ml} / \mathrm{min}$ speed, using a linear mobile-phase with a programmed gradient of three solvents: A (0.1\% ammonium acetate), B (Methanol), and $\mathrm{C}$ (acetonitrile) as follows: $\mathrm{t}=0 \mathrm{~min}, 75 \% \mathrm{~A}, 20 \% \mathrm{~B}, 5 \% \mathrm{C}$; $\mathrm{t}=10 \mathrm{~min}, 50 \% \mathrm{~A}, 45 \% \mathrm{~B}$, $5 \% \mathrm{C}$; $\mathrm{t}=15 \mathrm{~min}, 50 \% \mathrm{~A}, 45 \% \mathrm{~B}, 5 \% \mathrm{C}$. The APCI source was vaporized at $450{ }^{\circ} \mathrm{C}$; the nitrogen gas pressure was 80 and 20 psi respectively; and the capillary temperature was $150{ }^{\circ} \mathrm{C}$. The alkaloids were confirmed and identified by means of mass spectrometry (MS), comparing the spectra with the authentic samples (standards) and with spectral libraries.

\section{RESULTS AND DISGUSSION}

Table 1 shows the crude extract amounts of E. americana and E. coralloides, expressed as mg of crude alkaloids/100 $\mathrm{g}$ of dry weight of each plant material. In the case of $E$. americana, the highest amount of crude extract was found in the seeds of the fraction of free alkaloids in methanol, while for E. coralloides, the highest fraction was found in the calyx of the fraction of free alkaloids in methanol.

The tissue analysis shows a high concentration of free alkaloids in $\mathrm{CH}_{3} \mathrm{OH}$ and released alkaloids for both species; the concentration was lower for the fraction of free alkaloids in hexane. The hexane fraction was included because other studies (Hargreaves et al., 1974; Sotelo et al., 1993) have shown that it contains significant amounts of alkaloids. Some authors report that alkaloids represent 0.05 to $0.1 \%$ of the total plant of some species and that these substances were located in seeds, roots, bark, leaves, and flowers (Sotelo et al., 1993; Dyke and Quessy, 1981); however, the concentration and type of alkaloids present in calyx and corolla have not been mentioned in any reports.

Table 2 shows that the erysodine (1), erythrinine (5), $\alpha$-erythroidine (8), and $\beta$-erythroidine (9) alkaloids are distributed in both species; such alkaloids are characteristic of the species of the genus Erythrina found in the American continent. The erysovine (2) and erysopine (3) alkaloids were found only in the seeds of E. coralloides.

The erythraline (4), erythrinine (5), crystamidine (6), $\alpha$-erythroidine (8), $\beta$-erythroidine (9), and 8-oxo- $\alpha$-erythroidine (10) alkaloids were found in the E. americana calyx. The erythrinine (5), $\alpha$-erythroidine (8), $\beta$-erythroidine (9), and 8-oxo- $\alpha$-erythroidine (10) alkaloids were found in the corolla.

Table 1. E. americana and E. coralloides crude alkaloid fractions ( $\mathrm{mg} / 100 \mathrm{~g}$ dry tissue).

\begin{tabular}{l|c|c|c|c|c|c}
\hline \multicolumn{1}{c|}{ Specie } & \multicolumn{3}{c|}{ E. americana (mg) } & \multicolumn{3}{c}{ E. coralloides (mg) } \\
\hline Fraction & Calyx & Corolla & Seeds & Calyx & Corolla & Seeds \\
\hline Free alkaloids in hexane & 26 & 25 & 28 & 45 & 3.2 & 24.6 \\
\hline Free alkaloids in methanol & 167.9 & 88 & 662 & 520 & 201 & 489 \\
\hline Liberatedalkaloid fraction & 388 & 73 & 95 & 324 & 103.4 & 74 \\
\hline
\end{tabular}


Table 2. Content and distribution of total alkaloids in E. americana and E. coralloides.

\begin{tabular}{l|c|c|c|c|c|c|}
\hline \multicolumn{1}{|c|}{ Specie } & \multicolumn{3}{c|}{ E. americana } & \multicolumn{3}{c|}{ E. coralloides } \\
\hline Alkaloids & Calyx & Corolla & Seeds & Calyx & Corolla & Seeds \\
\hline 1.- Erysodine & & $*$ & $*$ & $*$ & $*$ & $*$ \\
\hline 2.- Erysovine & & & & & & $*$ \\
\hline 3.- Erysopine & & & & & & $*$ \\
\hline 4.- Erytraline & $*$ & & $*$ & $*$ & $*$ & $*$ \\
\hline 5.- Erytrinine & $*$ & $*$ & $*$ & $*$ & $*$ & $*$ \\
\hline 6.- Cristamidine & $*$ & & $*$ & $*$ & $*$ & $*$ \\
\hline 7.- 8-oxo-erytraline & & & $*$ & $*$ & $*$ & $*$ \\
\hline 8.- $\alpha$-erythroidine & $*$ & $*$ & $*$ & $*$ & $*$ & \\
\hline 9.- $\beta$-erythroidine & $*$ & $*$ & $*$ & $*$ & $*$ & $*$ \\
\hline 10.- 8-oxo- $\alpha$-erythroidine & $*$ & $*$ & $*$ & $*$ & & $*$ \\
\hline 11.- MW 289 & & & $*$ & & & $*$ \\
\hline 12.- MW 465 & & & & & $*$ & $*$ \\
\hline
\end{tabular}

The same alkaloids were found in E. coralloides calyx and corolla, with the exception of 8-oxo- $\alpha$-erythroidine (10). The 8-oxo-erythraline (7) alkaloid was detected in the seeds of E. americana and in all the tissues of $E$. coralloides.

The structures found by means of this technique were diene (1-7) and lactonic (8-10) alkaloids. According to the spectra produced by HPLC-MS, an alkaloid with a PM of 289 (11) was observed in the seeds of E. americana, while an alkaloid with a PM of 465 (12) was found in the corolla of E. coralloides; these alkaloids had not been previously reported in these species. The HPLC-MS combination has the advantage of quickly and accurately determining the presence of alkaloids in a sample from a few milligrams. Likewise, the use of HPLC-MS technique allows the detection of a large number of alkaloidal structures in the calyx and corolla of the genus Erythrina. The use of their flowers in the preparation of traditional dishes benefits from this fact.

\section{CONGLUSIONS}

A large number of erythrinane alkaloids were found in seeds, calyx, and corolla. The use of seeds and flowers in the preparation of diverse traditional dishes can cause soothing and sedating effects in consumers, as a result of the presence of lactonic alkaloids. The HPLC-MS technique allowed the detection of alkaloids in the flowers and seeds of these species that had not been previously identified in other studies.

\section{ACKNOWLEDGEMENTS}

The authors would like to thank CONACyT for the grant awarded during this research.

\section{REFERENGES}

Chukwujekwu, J.C., Van Heerden, F.R., \& Van Staden, J. (2011). Antibacterial activity of flavonoids from the steam bark of Erythrina caffra thunb. Phytoteraphy Research. 25(1): 46-48. Doi: 10.1002/ptr.3159 
Dantas, M.C., De Oliveira, F.S., Bandeira, S.M., Batista, J.S., Silva, G.D., Alves. P.B., Antoniolli, A.R., \& Marchioro, M. (2004). Central nervous system effect of the crude extract of Erytrhina velutina in rodents. Journal of Ethnopharmacology 94(1): 129-133. Doi: 10.1016 / j.jep.2004.05.007.

Dyke, S. \& Quessy, S.N. (1981). Erythrina and related Alkaloids. In: Manske, R.F.H. (Ed.). The Alkaloids, vol. 18. New York, USA: Academic Press. ISBN: 9780124695184.

Games, D.E, Jackson, A.H., Khan, N.A., \& Millington, D.S. (1974). Alkaloids of some African, Asian, Polynesian and Australian species of Erythrina. Lloydia 37: 581-588. PMID: 4449405

Garin-Aguilar, M.E., López, V.S., Martínez, V.C.L., Valencia, D.T.G., Soto-Hernández, M., y Prado-Alcalá, R.A. (2009). Erisodina y receptores nicotínicos $\alpha 4 \beta 2$ del hipocampo dorsal en la consolidación de la memoria. Revista Latinoamericana de Química 37:206-217. ISSN. 0370-5943.

Garin-Aguilar, M.E., Valencia, D.T.G., Soto-Hernández, M., \& Kite, G. (2005). High-perfomance Liquid Chromatography-Mass Spectrometric analysis of Alkaloids extracted from seeds of Erythrina herbacea. Phytochemistry Analysis 16:302-306. Doi: 10.1002/pca.8219

Hargreaves, R.T., Johnson, R.D., Millington, D.S., Mondal, M.H., Beavers, W., Becker, L., Young, C., \& Rinehart, K.L. Jr. (1974). Alkaloids of american species of Erythrina. Lloydia 37: 569-580.

Krukoff, B.A., \& Barneby, R.C. (1973). Notes of species of Erythrina. VII. Phytologia 27:108-114.

Kumar, S., Pathania, A.S., Saxena, A.K., Vishwakarma, R.A., Ali, A., \& Bhushan, S. (2013). The anticancer potential of flavonoids isolated from the stem bark of Erythrina suberosa through induction of apoptosis and inhibition of STAT signalling pathway in human leukaemia HL-60 cells. Chemico-Biological Interactions 205(2): 128-137. DOI: 10.1016 / j.cbi.2013.06.020

Maier, U.H., Rodl, W., Deus-Neumann, B., \& Zenk, M.H. (1999). Biosynthesis of Erythrina Alkaloids in Erythrina crista-galli. Phytochemistry 52(3): 373-382. Doi: 10.1016 / s0031-9422 (99) 00230-7.

Saidu, K., Onah, J., Orisadipe, A., Olusola, A., Wambebe, C., \& Gamaniel, J. (2000). Antiplasmodial, analgesic, and anti-inflammatory activities of the aqueous extract of the stem bark of Erythrina senegalensi. Journal of Ethnopharmacology 71(1): 275-280. Doi: 10.1016/s0378-8741(00)00188-4.

Setti-Perdigão, P., Serrano, M.A.R., Flausino, O.A. Jr., Bolzani, V.S., Guimarães, M.Z.P., \& Castro, N.G. (2013). Erythrina mulungu Alkaloids are potent Inhibitors of neuronal nicotinic receptor. Currents in Mammalian Cells. PLoS ONE 8(12): 82-92. Doi: 10.1371/journal.pone.0082726

Sotelo, A., Soto, M., Lucas, B., \& Giral, F. (1993). Comparative studies of the alkaloidal composition of two Mexican Erythrina species and nutritive of the detoxified seeds. Journal of Agricultural and Food Chemistry 41:2340-2343. Doi: 10.1021/jf00036a023

Tanaka, H., Sato, M., Fujiwara, S., Hirata, M., Etoh, H., \& Takeuchi, H. (2002). Antibacterial activity of isoflavonoids isolated from Erythrina variegate against methicillin-resistant Staphylococcus aureus. Letters in Applied Microbiology 36(6):494-498. Doi: 10.1046/j.1472-765x.2002.01222.x.

Turton, K., Natesh, R., Thiyagarajan, N., Chaddock, J.A., \& Acharya, K.R. (2004). Crystal structures of Erythrina cristagalli lectin with bound N-linked oligosaccharide and lactose. Glycobiology 14(10): 923929. Doi:10.1093/glycob/cwh114

Yoshida, Y., Mohri, K., Isobe, K., \& Yamamoto, K. (2009). Biomimetic Total Synthesis of (士)-8Oxoerymelanthine. Journal Organic Chemistry. 74(16):6010-6015. Doi: 10.1021/jo901046k

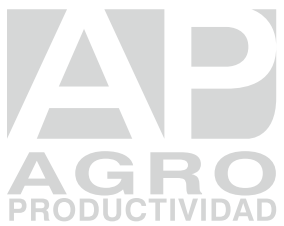

